\title{
SYSTEM-SYNERGETIC VIEW ON THE PROBLEM OF CULTURAL EVOLUTION
}

\author{
(C) Ivan P. Getmanov \\ Don State Technical University, \\ Rostov-on-Don, Russian Federation \\ igetmanov@mail.ru
}

The article develops the idea of cultural evolution and coevolution of cultures. The author applies an evolutionary-synergetic approach to substantiate his views. The notion of cultural attractor is used to justify the idea of coevolutionary unification of cultures. The patterns of cultural development are such that subsequent cultures are influenced by previous cultures. Humanity is in captivity of both ancient and new myths. The process of unification of cultures goes through a chaotic state, through periods of increasing entropy of social systems and national-ethnic cultures. The drama of cultural evolution lies in the fact that the mutual influence of cultures is not symmetrical. For the last two centuries, Western civilization has dominated in the socio-political, scientific and technical, and information technology fields. This has determined its dominance in the world. It is noted that different nations may dominate different areas of public life. It is also alleged that the acceleration of information processes and the formation of global information networks inevitably level the cultural differences of peoples. Three levels of coevolution of cultures are distinguished, each of which includes interactions between cultures simultaneous, one-space, different in time and different in space.

Key words: culture, evolution, co-evolution, mass culture, evolutionary-synergetic approach, levels of co-evolution, cultural attractor, unification of cultures.

\section{[И.П. Гетманов Системно-синергетический взгляд на проблему эволюции культуры]}

В статье развивается идея эволюции культуры и коэволюции культур. Для обоснования своих взглядов автор применяет эволюционно-синергетический подход. Понятие культурного аттрактора используется для обоснования идеи коэволюционной унификации культур. Закономерности развития культуры таковы, что последующие культуры находятся под влиянием предшествующих культур. Человечество находится в плену, как древних, так и новых мифов. Процесс унификации культур проходит через хаотическое состояние, через периоды повышения энтропии общественных систем и национально-этнических культур. Драматизм эволюции культуры заключается в том, что взаимовлияние культур не является симметричным. Последние два столетия Западная цивилизация доминировала в социально-политической, научно-технической, и информационно-технологической областях. Это обусловило ее доминирование в мире. Отмечается, что в различных областях общественной жизни могут доминировать различные нации. Также утверждается, что ускорение информационных процессов, формирование глобальных информационных сетей неизбежно нивелирует культурные различия народов. Выделяются три уровня коэволюции культур, каждый из которых включает взаимодействия между культурами одновременными, одно-пространственными, разновременными и разнопространственными.

Ключевые слова: культура, эволюция, коэволюция, массовая культура, эволюционносинергетический подход, уровни коэволюции, культурный аттрактор, унификация культур.

Ivan P. Getmanov - Ph.D. in Philosophy, Professor, Don State Technical University, Rostov-on-Don, Russian Federation.

Гетманов Иван Петрович - доктор фрилософрских наук, профрессор, Донской государственный технический университет, г. Ростов-на-Дону, Российская Федерация.

Modern Culture is usually understood as a system of "historically developing suprabiological programs of human activity, behavior and communication, acting as a condition for reproduction and change of social life in all its main manifestations" [1]. Pro- 
grammes of activity, behaviour and communication constitute the corpus of culture. They manifest themselves in various forms: knowledge, skills, norms and ideals, patterns of activity and behaviour, ideas and hypotheses, beliefs, social goals and value orientations, etc. These programs serve the function of preserving and transmitting the programs of people's activities, behavior and communication from generation to generation. The suprabiological programs ensure the reproduction of all possible forms of social life inherent in different types of society.

In European philosophy, culture is seen as an attributive property of hu-man existence, associated with the implementation of human life and distinguishing human existence from animal existence. Despite the many profound differences between the cultures of different peoples, modern mass culture unifies different cultures to a certain extent. This is due to the peculiarities of social life in the conditions of modern civilization. The latter is characterized by the information explosion, the introduction of information technology in all spheres of social life, and this is imposed on the processes of globalization. This feature of modernity predetermines not only the expansion of Western culture on a global scale, but also determines the processes of co-evolution and co-adaptation of multiple cultural systems.

In spite of the fact that it is not easy to apply the notions of evolution and co-evolution to the phenomenon of culture, it is even more difficult to use the evolution-synergetic approach as a methodological foundation to substantiate the vectorial direction of cultural evolution and fractal self-reproduction of cultural systems.

By evolution we mean any changes in the system based on the interactions between its links, as well as on the interactions of the system with the environment of its existence. The environment is other systems, the interactions with which reflect the philosophical principle of universal connection and interdependence of phenomena.

The dialectical doctrine suggests that the source of interaction and evolution of systems are contradictions. P.A. Sorokin described the cultural contradictions of the second quarter of the twentieth century in the following words: "The wave of death, bestiality and ignorance that swept over the world in the 20th century, civilized as it was thought, completely contradicted all the "sweet" theories of human progressive evolution from ignorance to science and wisdom, from an animal-like state to the nobility of mores, from barbarism to civilization, from "theological" to "positive" stage of society development, from tyranny to freedom, from poverty and diseases to unlimited prosperity and health, from ugliness to beauty, from man - the worst of animals to overman- demigod" [2]. In our opinion, this quotation by Sorokin reveals the methodological problem of the impossibility to fit the phenomenon of culture into the strict framework of slender theories. It refutes absolutization of the value system of a particular culture, which means that the values of some cultures may be in conflict with the values of other cultures. Hence the thesis: The cultures of different peoples are mutually influential systems.

The patterns of cultural development are such that subsequent cultures are influenced by previous cultures. Humanity is in captivity of both ancient and new myths. For example, the formation of national mythologies in the nineteenth and twentieth centuries enriched the set of archetypes with a new model - a chimerical fusion of the images of a mighty ancestor, a mighty descendant and a frail, declining contemporary. In ideology, this model is expressed by the thesis about the revival of the former greatness of one or other nation. This is most evident in the periods of stagnation and subsequent large-scale social transformations of individual nations, which is also characteristic of modern Russia.

In our concept of cultural evolution, we rely on the notion that ancient periodicity coevolutionally develop into a spiral of Christian rectilinearity (from creation to the Day of 
Judgment). Moreover, the vectors of the historical development of culture have different directions: from the initial point a lot of spirals diverge in different directions, filling the space of the cultural attractor. The at-tractor tends to narrowing (the model is a funnel), which causes the vectors set by the spirals of development to shrink to one point - the point of unification of cultures. The modern information explosion, acceleration of information processes, formation of global information networks inevitably levels the cultural differences of peoples and ethnic groups inhabiting the planet, and increasingly organize the system of "Earth civilization". But the organization of this system goes through a chaotic state, through periods of increasing entropy of social systems and nation-al-ethnic cultures.

The drama of cultural evolution in general (includes the co-evolution of in-dividual cultures) lies in the fact that the mutual influence of cultures is not symmetrical. This is due to the fact that universal culture includes all the richness of material culture, ethnic customs, diversity of languages and symbolic systems. Any fragments of the human world that acquire the function of signs fixing pro-grams of activity, behavior, and communication act as symbolic systems. Certain actions and deeds acquire the status of models for other people, various kinds of artificial languages appear and develop: the language of science, the language of art, etc. For the last two centuries, Western civilization has dominated in the socio-political, scientific and technical, and information technology fields. This has determined its dominance in the world. It is worth to note that different nations may dominate different areas of public life.

Man-made objects of the second nature act as special signs, which fix the accumulated social experience, predetermine a certain way of human behavior and activity in the objective world. Tools, machinery, everyday objects constitute the framework of material culture, which is opposed to the phenomenon of spiritual culture. Spiritual culture includes works of art, philosophical, ethical, political dogmas, scientific knowledge, religious ideas, etc. It should be clarified that this opposition is relative because any cultural phenomenon is a semiotic formation. Thus, objects of material culture play a dual role in human life: they serve a practical purpose and at the same time act as a means of storing and transmitting socially relevant information. It is in their second function that they act as cultural phenomena.

The evolutionary-synergetic approach to explain cultural evolution relieves researchers from linear thinking. Thus, the discovery of cyclical phenomena and comprehension of historical disasters lead to the identification of cycles, rhythms, phases and periods in history, politics, economics, art, etc. We believe that when considering the evolution of culture, we should be based on the idea of equality of cycles, spirals, cycles of development [3]. The "braid of historical development", which represents the coevolutionary intertwining of densely stacked bundles-processes of socio-cultural development in a single multifaceted flow of human history, can be modeled. Co-evolutionary phenomena are based on social pro-grams of life activity (behavior, communication), which represent a variety of cultural phenomena, united in a complex hierarchical organization. Three levels of coevolution can be distinguished in them.

The first level of cultural co-evolution is represented by relic programs, these are fragments of past cultures, which live in the modern world, having a certain impact on the person (co-evolution of past experience and the present). It is known that people often act unconsciously, according to the programs of behavior, which developed in the primitive epoch and which have lost their value as a rational regulator of actions. Relic programs include many superstitions and taboos of the primitive epoch, which were of great im- 
portance for building relations in the primitive society during the period of the group family, eliminating clashes in the community and ensuring efficient joint productive activities.

The second level of coevolution of cultures is those programs of behavior, activity and communication, which ensure the current functioning and reproduction of a particular type of society. In modern history one can find a lot of examples of attempts to change the social and economic mode of social life by exporting algorithms of public life alien to a given nation. As a rule, such attempts end in failures and humanitarian disasters for the people to whom an alien model of social organization was forcibly imposed. This has happened in Iraq, Libya, Syria, Afghanistan and elsewhere. The process of coevolutionary changes of cultures implies a gradual or abrupt transition to a new qualitative state due to internal contradictions, leading to a more sustainable and successful functioning of the state-society organism.

The experience of value shifts among Russian citizens over the past two decades is quite instructive. Contrary to the social time theory of ethnicities and peoples, there are striking similarities in manners and lifestyles in the West and in contemporary Russia. We have adopted the vices of Western civilization before we even mastered its achievements. The processes of globalization represent the victory of neoliberalism on a global scale, have brought the idea of the economic man to Russia [5]. The objective generation of mass culture by Western capital-ism at the stage of consumer society has been described quite extensively in the literature. And both the East (Southeast Asia) and Russia have absorbed the mass culture of the United States. The young generation sees in it something most advanced and modern, overcoming conservatism and backwardness, it is charged with its energy. It is shaped by this culture in a consumerist spirit over-laid with national ethics. But the principal difference between the consequences of the Western mass cultural expansion is this: In the East, mass culture played a mobilizing role in the development of production and the modernization of societies. In Russia, mass culture had a political basis, but without an economic base it became a means of demoralizing the young and not just the young generation. Thus, we can quite assert that the vector of unification of cultures is quite objective in the historical perspective.

The third level of coevolution of cultural phenomena is formed by those programs of social life, which are addressed to the future (the present, past and future trialectics [4]). Future-oriented ideas are generated by culture through the internal operation of sign systems. At the same time every culture is influenced by other cultures and itself has some influence on them. We are often dealing with international agendas that influence emerging cultural systems. Science produces theoretical knowledge that triggers a technical and technological revolution, laying the foundations for technology in subsequent eras. Social science is crystallizing the ideals of the future social order, which have not become the dominant ide-ology yet. New moral principles are being formed in the humanitarian sphere, of-ten ahead of their time. Thus, natural-science and socio-economic theories, philosophical and ethical concepts appear as models of future activity programs and prerequisites for social change. In a highly dynamic society, there is great value in cultural creativity directed towards the future.

In conclusion, it can be noted that the levels of cultural co-evolution de-scribed in the article include interactions between cultures of different times and different dimensions. Any changes in culture arise only through the creative activity of the individual. Man, as a creature of culture, is also its creator.

The problem of the hierarchization of cultures, like the hierarchization of biological structures, remains open. The present article is the author's feasible contribution to the proof of cultural evolution and coevolution of cultures. 


\section{Лumepamypa}

1. Новейший фрилософский словарь: 2-е изд., переработ. и дополн. Мн.: Интерпрессервис; Книжный Дом, 2001.1280 с. (Мир энциклопедий). С. 527.

2. Сорокин П.А. Долгий путь. Автобиографический роман. Сыктывкар: Шыпас, 1991. C. 167.

3. Гетманов И.П. Ментальные структуры русского национального сознания // Актуальные проблемы науки и техники. 2018. [Электронный ресурс]: Материалы нац. Науч.-практ. конф: (Ростов-на-Дону, 12-14 марта 2018г.); Донской гос. техн. ун-т. Ростов-на-Дону: ДГТУ, 2018. 728 с. URL: https://ntb.donstu.ru/conference. ЭБС ДГТУ. Загл. с экрана. С. 689-691.

4. Жданов Ю.А. Избранное: В 2 т. Т. 2. Ростов н/Д, 2001. 368 с.

5. Федотова В.Г. Факторы ценностных изменений на Западе и в России // Вопросы филлософиии. 2005. № 11.

\section{References}

1. Noveyshiy filosofskiy slovar: 2-ye izd., pererabot. i dopoln. [The latest philosophical dictionary: 2nd ed., Revised and enlarged]. Minsk: Interpresservis; Knizhnyy Dom, 2001. 527 p. (in Russian).

2. Sorokin P.A. Dolgiy put. Avtobiograficheskiy roman [Long way. Autobiographical novel]. Syktyvkar: Shypas, 1991. 167 p. (in Russian).

3. Getmanov I.P. Mentalnyye struktury russkogo natsionalnogo soznaniya. Aktualnyye problemy nauki i tekhniki. 2018. Materialy natsionalnoy Naucho-prakticheskoy konferentsii: (Rostov-na-Donu, 12-14 marta $2018 \mathrm{~g}$ ) [Mental structures of Russian national consciousness. Actual problems of science and technology. 2018. Materials of the National Scientific and Practical Conference: (Rostov-on-Don, March 12-14, 2018)]. Rostov-na-Donu: DGTU, 2018. Available at: https://ntb.donstu.ru/conference. EBS DGTU. pp. 689-691 (in Russian).

4. Zhdanov YU.A. Izbrannoye: v 2 t. [Selected: in 2 volumes]. V. 2. Rostov-on-Don, 2001. 368 p. (in Russian).

5. Fedotova V.G. Faktory tsennostnykh izmeneniy na Zapade i v Rossii. Voprosy filosofii. [Factors of value changes in the West and in Russia. Philosophy questions]. 2005. No. 11 (in Russian). 